Volume 8, No.5, September - October 2019

International Journal of Advanced Trends in Computer Science and Engineering

Available Online at http://www.warse.org/IJATCSE/static/pdf/file/ijatcse10852019.pdf

https://doi.org/10.30534/ijatcse/2019/10852019

\title{
Formation of reputation in semantic fields
}

\author{
D.V.Volkov', M.V.Zubov ${ }^{2}$, A.G.Masehnovich ${ }^{3}$ \\ ${ }^{1}$ Expert, Russian State Social University, Moscow, Russia, volkovdv@gmail.com \\ ${ }^{2}$ Senior software engineer, Integrated Systems, Moscow, Russia, mvzubov@gmail.com \\ ${ }^{3}$ Project manager, Integrated Systems, Moscow, Russia, agmasehnovich@gmail.com
}

\begin{abstract}
The semantic field of a certain community has many useful properties that can be used to promote the product. People belonging to the semantic form their own strategy of promoting goods and services, which subsequently consume all members of this society. The relevance of this article is to study the factors affecting the formation of reputation for goods and services within the semantic fields. The heterogeneity of the phenomena of semantic fields in modern institutions does not reduce the qualitative properties provided for the study of this kind. The object of the study is the relationship within the semantic field, the subject of the study are the processes of formation of reputation in the semantic fields.
\end{abstract}

Keywords: reputation in society, competitiveness of goods, market analysis, semantic field.

\section{INTRODUCTION}

In recent decades, there has been an increased interest in the reputation of the organization both in society as a whole and on the part of the organizations themselves. The individual, in deciding to cooperate with an organization, has in many cases become guided by information about the reputation of the organization, as the supply of goods and services in the market is a set of elements that are difficult to analyze. Thus, reputation has become, on the one hand, an important category that characterizes public opinion about the organization, on the other - one of the most important assets of the organization, as the process of formation of this asset occurs in the interaction of society and the organization. On the one hand, and on the other hand, it can be formed by society directly in the semantic field.

The formation of the reputation of the organization covers its activities in all areas - production, Finance, economy, innovation, personnel, ecology, relations with state and regulatory authorities, participation in social projects, which ultimately has a significant impact on the formation of the social structure of society. Each of these areas is a specific activity [21-31].

Surprisingly, among the system researchers of the reputation of the organization can be identified no more than a dozen scientists. In Russian scientific circles, the topic of reputation formation at this stage has not received systematic development.
Today, there is no doubt that goodwill is the most important intangible asset of the enterprise, despite the fact that it differs significantly from other intangible assets in the content, methods of acquisition or disposal, methods of evaluation.

Experts agree that a good reputation makes the company more attractive to investors, increases its capitalization, allows increasing income provides a stronger position when entering new markets and support the General public [12]. Scientists publish the results of studies proving the positive impact of reputation on other parameters of the business model. No doubt, it is necessary to manage reputation.

The development of globalization of the world economy and the increasing interdependence of economic entities of different countries have the consequence of the expansion of international trade and investment cooperation, which in turn determines the increasing role of mediation.

Improving the international competitiveness of Russia and the implementation of the transition of the domestic economy to an innovative type of development depends not only on the diversification of the sectoral structure of the economy and increasing the quality of products, but also on the use of modern management systems and marketing technologies, quantitative and qualitative development of operations of Russian intermediary companies in the field of international business. These indicators form the reputation of the state. What is reflected in the media information resources [13].

Russia's integration into the world economy and our country's accession to the world Trade Organization create new opportunities for domestic companies to develop international business, as well as certain threats from foreign competitors. In order to take full advantage of open access to foreign technology and markets, as well as to withstand the growing competition from foreign producers of goods and services, national companies need scientific understanding of the most important aspects of international business [2]. These terms are also referred to as turbulence. This term can be attributed to the formation of reputation. In this context, reputation is applicable both for society - the reputation of the state in the eyes of society, and for the counterparty - reputational risks in interaction (economic, political). The relativity of the concept of reputation is also important to consider [18, 19]. Formation of reputation in public groups in Russia requires not only development and modernization, but also high service. The problem of ensuring and maintaining the amount of historical and cultural heritage should be taken 
over not only by the public sector, but also by the commercial sector and entrepreneurs [17]. These projects require funding, so you should use not only the classic ways to attract capital, but also socio-cultural methods that will benefit entrepreneurs, individuals.

Formation of reputation in public groups - is a comprehensive definition that includes a system of existing concepts related to the activities of communities of people with respect to the object under study. It can be concluded that advertising, marketing and sales are an integral part in improving the efficiency of doing business, forming a reputation. It is necessary to have a highly profitable production, which allows to develop and cover the cost of production and the formation of its reputation. The formation of the concept of development is based on the laws of the market. The formation of marketing can be considered at the state level and put into practice in terms of the legislative framework, which requires modernization.

The main task of development at the national and international level is to attract foreign investors, which in turn will fill the state budget and invest money in infrastructure to create jobs and increase the wealth of the country. The educational component will motivate and teach the future generation to assess the cultural heritage and develop it in a market economy.

\section{METHODS}

To improve the quality of the study, the following list of methodological tools was chosen:

1. The method of abstraction - Theoretical-empirical method. This method allows in the process of performing analytical and design work to escape from the random, situational, from non-essential properties, relationships and relationships of the phenomenon under study, in our case, the formation of reputation.

2. Method of alternatives - This method improves the quality of the work performed by objectifying the procedure for choosing a method of solving a specific problem, because when it is used, different alternatives, options for action, answering a question, options for solving the problem are put forward (Grover, P. et al, 2019); then these options/alternatives are discussed (for example, by a group of experts and with the involvement of a wide range of practitioners) for the final choice of the optimal solution.

3. The method of analysis is a Theoretical and empirical method, the dismemberment of the whole object into its component parts (sides, features, properties or relations) for the purpose of their comprehensive consideration.

4. Methods of mutual influence analysis - This method improves the quality of work performed by analyzing the influence of various factors on the studied problem [11]. Consideration of the reasons for a particular distribution, its availability, volume or lack thereof in certain countries, for example in our case, will be reflected to form a complete picture of the phenomenon of reputation formation.

5. The method of analysis and systematization of data - This method involves the structuring of the materials obtained in the course of analytical actions, followed by the unification of previously disparate concepts and judgments in qualitatively new information [16]. Data analysis and systematization will be used in most project activities to improve the quality of work and in future studies.

6. Analysis method range of subproblem Method of analysis of the range of subproblem is to decompose the original problem into interdependent components, taken separately, the components of subproblem (as a rule, subject to hierarchical subordination) [3]. Then, all possible combinations of the components of the problem are compiled, for each of which a particular draft decision is drawn up. The use of this method will reduce the time of the analysis of the problem and the preparation of the required materials, improve the quality of work.

7. The method of analysis of problems - Choosing the research method subproblem, we couldn't pass the method the main problems. This method is used to solve the problems of choice of alternatives by means of their multi-criteria rating [5]. The method allows to analyze the problem. In this case, the problem is presented in the form of hierarchically ordered: a) the main goal (the main criterion) of rating possible solutions, b) several groups (levels) of the same type of factors, one way or another affecting the rating, c) groups of possible solutions, d) a system of links indicating the mutual influence of factors and solutions.

The task of development at the national and international level to attract foreign investors, which in turn will allow to fill the state budget and invest in infrastructure to create jobs and increase the wealth of the country. The educational component will motivate and teach the future generation to assess the cultural heritage and develop it in a market economy.

\section{LITERATURE REVIEW}

Most of the scientists working on the problems of forming the reputation of the organization are practical scientists. Among them are: A. Sitnikova, G. hanov, V. Pakhomov, D. Borodin, D. Metz, I. kuzmenkova, A. Shmarova, J. Polunina.

Among the well-known foreign experts in the field of forming the reputation of the organization can be identified K. Fombrun, K. FOSS, D. Kartalia, G. Dowling.

The theoretical formation of information about the reputation formula today in social networks, organizations and other semantic fields is represented by disparate research in various fields of scientific knowledge. The complexity of the study lies in the polyparadigmatic nature of the phenomenon. Thus, some researchers consider this phenomenon in terms of commitment to the rational choice of communities, and some cause the phenomenon as the formation of identity in the community. That is, according to the actual data, we have two main approaches: from the point of view of the individual and serving only her needs, and then commitment to choosing based on their own positive knowledge about the phenomenon, and on the other hand, the formation of the phenomenon based on the influence of society on the individual, thus, the formation of continuity in the formation of reputation.

The paradigm of reputation theory is the generally accepted postulates of public opinion about certain individuals, organizations, etc. [4]. 
The formation of the opinion of the individual and the public as a process in the studies of Russian and foreign scientists appears in the form of a dynamic indicator with a double scale. Reputation can be both positive and negative [1]. And the image can be created as in contact directly with the object, and without it, but using information about the experience of another person [20].

\section{DISCUSSION}

Management in the plane allows you to achieve effective solutions that bring the most cost-effective solution. The formation of a common approach to the development of intermediaries in improving the efficiency of international business is an opportunity in the implementation of national and international projects. The key to success in the development of the complex is based on the high professionalism of the performers, representatives of the country $[18,19]$.

The formation of the national brand as a center in the international community is a painstaking work that requires regular maintenance of the image of compliance with the international service, as well as the development of existing national values. The formation of reputation as a phenomenon can actually be seen on the example of any object.

The investment climate depends on a number of components, namely external and internal factors of the country. The investment component depends on the quality of products, production potential, image [9]. Development in Russia depends on high technologies that require investment. The technological component will reduce the cost, which in turn will reduce the price it will be a competitive advantage, forming a [14]. Competition in the country's sector is quite high. Exports must meet international standards and be of high quality. Communication with the international community is an integral component that allows to differentiate the range of raw materials and products. Each economic parameter of the country forms public opinion and a kind of reputation.

As for the enterprises or firms, for the formation of reputation use tools such as advertising. Advertising - is the engine of business development, without advertising and marketing business can not be effective in [15].

Each company has its own strategy, mission, strategy, which forms a reputation about it.

Strategic planning allows you to feel confident in the future. Motivational component in the team, sales Department will achieve high profitability, to realize the planned goal in the form of financial calculations on a bonus, premium basis. As for the team, the corporate spirit also forms a reputation within the company and beyond.

So, with regard to the phenomenon of reputation, we can draw an unambiguous conclusion that it is public opinion about a particular phenomenon or object. In the question of the reputation of the individual in society, it is important to emphasize a number of factors that characterize the individual as an individual in society [10]. Most often, identification occurs in the manner of communication, actions, appearance, personal positioning, reaction to what is happening around.

Identifying information about the person it is possible to extrapolate the data and to the company. But this already implies that the company is at a point formed by a certain reaction on yourself. Thus, corporate reputation is how the company is evaluated by other market participants: raw material suppliers, consumers of products, direct and indirect competitors, the business community (including potential investors and creditors), the authorities. The main components of the relationship include [8]:

1. Reputation of the company as a business partner: what suppliers, customers of products, other firms located above and below in the production chain, members of the Association, which may include the company and other partners, think about the company.

2. Reputation of the company as a place of work: what do its employees and employees of other companies in the industry think about the company.

3. Reputation of the company as a participant of financial relations: what do they think about the company investors and creditors.

4. Company reputation in the business community: what people think about the company:

- its competitors and companies operating in the same industry;

- heads of companies in other industries.

5. The company's reputation among consumers and "the people": what people think about:

products (services) of the company;

professionalism of its employees;

her role in society.

6. The company's reputation in the media: what is written about the company in Newspapers, magazines, online publications, including industry and "General" direction.

7. Reputation of the company in power structures: what the management of the city, area, the state thinks of the company.

All these aspects of business reputation are connected, but independent. After all, the opinion of the media can influence the opinion of consumers, and can reflect it; if the authorities do not actively like the company, investors are likely to consider it a risk factor; state-owned enterprises in any case are in good standing with the authorities, but the opinion of consumers about them may not be so unambiguous good; etc.

In a study conducted in 2015 by the consulting Agency The PBN Company, there was a question $[18,19]$ : "What are the main risks for the corporate reputation of the Russian company?". The respondents ' answers were as follows:

- Negative results of the company's activity, decrease in profit (63\% of respondents).

- Conflict with authorities (48\%).

- Tendentious press coverage of the company's activities (47\%).

At the same time, the conflict with employees seems to be "unimportant" - only $8 \%$ of Russian companies noted this threat (the last place). This means that companies are least afraid of social tensions or, for example, situations related to industrial accidents, environmental problems. The main risks for them were at that time in the sphere of relations with the state $[6,7]$.

Nevertheless, it is useful to pay attention not only to the "most important". It is possible that in our company the most painful place is the relationship with employees. This problem can indirectly affect the company's performance, including its profit. In addition, relations with employees and the formation of a single corporate culture can be the 
lever by which our company will rise to a new level of development.

Managing corporate reputation, we can not pay attention to only one audience (for example, the authorities). We will have to engage in dialogue with all audiences inside and outside the company.

\section{CONCLUSION}

Sooner or later, any company faces the need to purposefully build its reputation. This is primarily due to the need to ensure the dynamic development of the company, attract investment and improve its competitiveness. The preferred option is a situation where, against the background of well-being, the company lays the foundations for future stability in the form of investments in reputation.

Reputation is a dynamic characteristic of the company's behavior, which is formed in the society for quite a long period of time. It is formed on the basis of a set of information on how and by what methods the business structure builds its behavior in certain situations.

Reputation building is carried out in the course of all activities of the organization, affecting relationships with all groups of contractors, and ultimately aims to form a positive public opinion about the company, which becomes a factor that encourages interaction with it.

Reputation management is an integral element of the company's competitive behavior. This is a systematic process, which ideally aims to acquire the company's "good name" through its self-improvement.

In Russia, the banking sector began to deal with reputation issues before anyone else. Banks began to build their reputation even before the concept of "reputation management"entered into Russian scientific and practical use.

Reputation is an invaluable capital of the enterprise. Losing a good name, "losing face" in the conditions of developed market relations means the end of an entrepreneur's career, the collapse of the enterprise.

\section{ACKNOWLEDGEMENT}

This research was financial supported by the Ministry of Science and Higher Education of the Russian Federation under the unique research id RFMEFI57917X0143.

\section{REFERENCES}

1. Ageeva, E., Melewar, T.C., Foroudi, P., Dennis, C. Cues adopted by consumers in examining corporate website favorability: An empirical study of financial institutions in the UK and Russia. Journal of Business Research. Volume 98, May 2019, Pages 15-32

https://doi.org/10.1016/j.jbusres.2018.12.079

2. Ahmed, A.I.A., Khan, S., Gani, A., Ab Hamid, S.H., Guizani, M. Entropy-based Fuzzy AHP Model for Trustworthy Service Provider Selection in Internet of Things. Proceedings - Conference on Local Computer Networks, LCN. Volume 2018-October, 8 February 2019, Номер статьи 8638056, Pages 606-613

3. Borodin D. Reputation as a subject of modern PR-activity// Reputation of the organization: creation, management, protection: materials of the seminar, Moscow, April 12, 2002.

4. Calvaresi, D., Dubovitskaya, A., Retaggi, D., Dragoni, A.F., Schumacher, M. Trusted Registration, Negotiation, and Service Evaluation in Multi-Agent Systems throughout the Blockchain Technology. Proceedings - 18th IEEE/WIC/ACM International Conference on Web Intelligence, WI 2018; Santiago; Chile; 3 December 2018 до 6 December 2018. 10 January 2019, Pages 56-63

https://doi.org/10.1109/WI.2018.0-107

5. Egorov S. Macroeconomics of reputation. Reputation management in the banking sector // Proceedings of the seminar "Reputation of the organization: creation, management, protection" April 12, 2002.

6. Gavra D. "Compromise of interests of business, society and government - myths and reality"// Business reputation and social responsibility of business: proceedings of the conference, Yaroslavl, October 22-23, 2003.

7. Grover, P., Kar, A.K., Ilavarasan, P.V. Impact of corporate social responsibility on reputation-Insights from tweets on sustainable development goals by CEOs. International Journal of Information Management. Volume 48, October 2019, Pages 39-52

https://doi.org/10.1016/j.ijinfomgt.2019.01.009

8. Kleymenov V. Reputation in the service sector. Formation of business reputation of the insurance company on the example of ROSNO // Reputation of the organization: creation, management, protection: materials of the seminar, Moscow, April 12, 2002.

9. Maloletko, A., Volkov, D., Vishnyakova, V., Shatsky, A. The effect of supply chain and consumer preferences on the formation of economic model. International Journal of Supply Chain Management. Volume 7, Issue 5, October 2018, Pages 684-689

10. Maslov M. Reputation Management of Russian companies in the Western markets // Reputation of the organization: creation, management, protection: materials of the seminar, Moscow, April 12, 2002 C77-82.

11. Oganyan, V.A., Vinogradova, M.V., Volkov, D.V. Internet piracy and vulnerability of digital content. European Research Studies Journal. Volume 21, Issue 4, 2018, Pages 735-743

12. Pakhomov V. How is the reputation and business image of banks estimated// Direct-info №20, 2002.

13. Punyatoya, P. Effects of cognitive and affective trust on online customer behavior. Marketing Intelligence and Planning. Volume 37, Issue 1, 4 February 2019, Pages 80-96

https://doi.org/10.1108/MIP-02-2018-0058

14. Rodionov I. Impact of changes in the quality of corporate governance on the value of Russian companies // Rodionov I., Stasyuk P./ M.. - 2004. - P. 6-9. 15. Rostov N. Transparent management // Consultant. - 2005. - №1. - P. 26-28.

16. Ureña, R., Kou, G., Dong, Y., Chiclana, F., Herrera-Viedma, E. A review on trust propagation and opinion dynamics in social networks and group decision making frameworks. Information Sciences. Volume 478, April 2019, Pages 461-475

https://doi.org/10.1016/j.ins.2018.11.037 
17. Volkov D. V. Analysis of the structure of the modern monetary system. Economy: yesterday, today, tomorrow. 2016. Vol.6. No. 10A. P. 161-170.

18. Volkov, D.V., Maloletko, A.N., Kaurova, O.V. Formation of bounded consumers' rationality based on micro-segmentation. European Research Studies Journal. Volume 21, Issue 4, 2018, Pages 754-762

19. Volkov, D.V., Vinogradova, M.V., Kulyamina, O.S. The synthesis of modern consumer preferences with the use of social networks in supply chain. International Journal of Supply Chain Management. Volume 7, Issue 5, 2018, Pages 851-857

20. Wai Lai, I.K. Hotel image and reputation on building customer loyalty: An empirical study in Macau. Journal of Hospitality and Tourism Management. Volume 38, March 2019, Pages 111-121.

21. Cherkasov, A.A., Bratanovskii, S.N., Koroleva, L.A., Tarakanov, V.V. Expedition in khevsureti in 1813. The "assault" of Shatili. Bylye Gody. 2019.51 (1). P. 166 -175 . https://doi.org/10.13187/bg.2019.1.166

22. Fominykh, N.Y., Zarudnaya, M.V., Enygin, D.V., Galakhov, D.V., Epifanov, D.A., Eferova, A.R. Methodological approaches to university instructors professional foreign languages competence development. The Journal of Social Sciences Research. 2018. Special Issue. 5. P. $375-381$.

23. Cherkasov, A.A., Koroleva, L.A., Bratanovskii, S., Ter-Oganov, N. The Russian-Turkish and RussianPersian front line on the eve of and during the patriotic war of 1812. Bylye Gody. 2019. 52 (2). P. 585 - 595.

https://doi.org/10.13187/bg.2019.2.585

24. Adygezalova, G.E., Allalyev, R.M., Kiseleva, A.V., Grigorieva, N.A. Copyright violation and distribution of prohibited content on the internet: Analysis of legal arrangements in the legislation of the Russian Federation. Journal of Advanced Research in Law and Economics. 2018.9 (1). P. 6 - 14.

25. Zatsepin, A.M., Zatsepin, M.N., Filippova, O.V., Allalyev, R.M., Fatkullina, A.A. The influence of addiction to gambling on the civil capacity of citizens. European Research Studies Journal. 2018. 21(4). P. 588 599.

26. Cherkasov, A.A., Ivantsov, V.G., Šmigel', M., Bratanovskii, S.N. Evolution of the institution of the slave trade in the caucasus in the IV-XIX centuries. Bylye Gody. 2018.50 (4). P. 1334 - 1346.

https://doi.org/10.13187/bg.2018.4.1334

27. Magsumov, T.A., Nizamova, M.S., Artemova, S.F., Allalyev, R.M. The Akhal-Teke expeditions of 1879-1881 years: Historical and statistical study. Part 1. Bylye Gody. 2019. 53 (3). P. 1256 - 1262. https://doi.org/10.13187/bg.2019.3.1256

28. Bondarenko, N.G., Allalyev, R.M., Smirnov, M.G., Dudchenko, A.V., Strizhova, E.V. History and main trends in the development of copyright. Journal of Advanced Research in Law and Economics. 2018.9 (1). P. $41-47$.

29. Karataev, V.B., Markaryan, I.N., Allalyev, R.M. To the issue of historical prerequisites and the significance of the construction of the railway network in the Caucasus (the late 19th and early 20th Century era). Bylye Gody. 2015. 38 (4). P. 933 - 939.
30. S.V.R.K.Rao, M.Saritha Devi, A.R.Kishore and Praveen Kumar Wireless sensor Network based Industrial Automation using Internet of Things (IoT). International Journal of Advanced Trends in Computer Science and Engineering. 2018. Volume 7 No. 6 (2018). Pages 82-86 https://doi.org/10.30534/ijatcse/2018/01762018

31. Ramakrishna Rath, R.Tamilkodi, K V Mishra and K Jose Cherian Utilizing Contemporary Benchmark Protocol for Sharing Mobile Ad-hoc Network Environment. International Journal of Advanced Trends in Computer Science and Engineering. 2018. Volume 7 No. 6 (2018). Pages 96-98

https://doi.org/10.30534/ijatcse/2018/04762018 